\title{
THE SERUM LIPIDS IN MEN RECEIVING HIGH CHOLESTEROL AND CHOLESTEROL-FREE DIETS *
}

\author{
By WILLIAM E. CONNOR, ROBERT E. HODGES AND ROBERTA E. BLEILER \\ (From the Department of Internal Medicine, State University of Iowa College of Medicine, \\ Iowa City, Iowa)
}

(Submitted for publication November 21, 1960; accepted February 2, 1961

In a previous study we found that dietary cholesterol provided in the form of egg yolk had a great effect upon the serum cholesterol and phospholipid levels in healthy human subjects (2). This effect was obtained with the use of high cholesterol and cholesterol-free diets which were balanced closely in the amounts of fat and in fatty acid composition. The range of cholesterol intake so tested was from 1,700 to $4,800 \mathrm{mg}$ per day, amounts clearly above the usual daily American consumption of 500 to $1,000 \mathrm{mg}$. The present investigation was designed to examine the serum lipid responses of six men given dietary cholesterol as egg yolk in amounts compatible with usual dietary intakes. The effects of egg yolk cholesterol and crystalline cholesterol were also compared.

\section{METHODS}

Subjects. Six men, aged 41 to 52 years, were selected from prison volunteers and hospitalized on a metabolic ward for 13 weeks. After a complete medical examination they were found to be in good health; none was obese. Their urinalyses, blood counts, erythrocyte sedimentation rates and chest $\mathrm{X}$-rays were normal.

Dietary plan. Initially, the men received a general diet for 1 week (3,000 calories, $70 \mathrm{~g}$ protein, $120 \mathrm{~g}$ fat, and $425 \mathrm{mg}$ cholesterol). They then were given various experimental formulas as the sole source of nourishment for the next 12 weeks. Each man received the formula in three separate meals administered through an intragastric tube in order to insure precise quantities of each nutrient.

Aside from differences in their content of egg yolk and crystalline cholesterol, the formulas of all subjects were identical for each period (Table I). The caloric content was 3,000 ; the protein was $70 \mathrm{~g}$ derived from casein,

\footnotetext{
* Presented in part at the Annual Meeting of the American Heart Association, Council on Arteriosclerosis, St. Louis, October 21, 1960 (1). Supported by research grants from the National Institutes of Health, the American and Iowa Heart Associations, the Nutrition Foundation, the National Vitamin Foundation, and the American Cancer Society.
}

except during period II when small components of the total protein were derived from egg yolk. The carbohydrate was supplied from a mixture of cornstarch, Dextrimaltose and sucrose. The basic formula contained normal amounts of required vitamins and minerals.

In each period the fat supplied 40 per cent of the total calories. It consisted of a vegetable oil mixture, 60 per cent peanut oil, 30 per cent cocoa butter and 10 per cent safflower oil. It was designed to have a fatty acid composition similar to that of egg yolk. During period II small amounts of fat were provided from egg yolk-i.e., from 8 to 25 per cent of the total fat for the three different groups. The fatty acid composition of the egg yolk and vegetable oil mixtures was determined by gasliquid chromatography. 1 The fatty acid data of Table I were computed on the basis of these analyses. Thus, the iodine values and the percentage of saturated, monoethenoid and polyethenoid fatty acids were virtually identical for all periods and all subjects. Only the quantity of cholesterol in the diet was varied.

The diets were changed every 3 weeks in order to compare the effects of cholesterol-free diets with diets containing cholesterol. These periods were numbered from I to IV chronologically. The diets of periods I and III were cholesterol-free and identical for all subjects. The diet of period II contained cholesterol in the form of egg yolk: the two men in group A received 475 $\mathrm{mg}$ per day, the two men in group B consumed $950 \mathrm{mg}$, and the two men in group $C$ received $1,425 \mathrm{mg}$. During period IV, crystalline cholesterol was blended into the formulas in a different amount for each group: group A $1,200 \mathrm{mg}$ per day, group B 2,400 mg, and group C 3,600 mg.

Laboratory studies. Blood was drawn twice weekly from each subject after a 14 hour fast. The total cholesterol $(3,4)$, phospholipid (5) and triglyceride (6) were determined in duplicate on each serum specimen during all periods. The two serum determinations for each subject during the last week of each dietary period were averaged to provide a final figure which then was used for an indication of the effect of a given diet.

The Zak method for serum cholesterol determination was found to have improved accuracy when performed at a constant room temperature of $23^{\circ}$ to $24^{\circ} \mathrm{C}$ and when the concentrated sulfuric acid was added rapidly to the ferric chloride-glacial acetic acid solution containing the

\footnotetext{
1 Through the courtesy of Dr. Fred Mattson, Procter \& Gamble Co.
} 
TABLE I

Compostion of the formulas for the different dietary periods*

\begin{tabular}{|c|c|c|c|c|c|c|c|c|c|c|c|c|}
\hline \multirow[b]{2}{*}{ Period } & \multirow{2}{*}{\multicolumn{2}{|c|}{ Subjects }} & \multirow[b]{2}{*}{$\begin{array}{c}\text { Choles- } \\
\text { terol }\end{array}$} & \multicolumn{2}{|c|}{ Source of fat } & \multirow[b]{2}{*}{$\begin{array}{l}\text { Iodine } \\
\text { value }\end{array}$} & \multicolumn{3}{|c|}{ Fatty acids } & \multicolumn{2}{|c|}{ Protein } & \multirow[b]{2}{*}{ Cystine } \\
\hline & & & & $\begin{array}{l}\text { Egg } \\
\text { yolk }\end{array}$ & $\begin{array}{c}\text { Vegetable } \\
\text { oil } \\
\text { mixture }\end{array}$ & & $\begin{array}{l}\text { Satu- } \\
\text { rated }\end{array}$ & $\begin{array}{l}\text { Mono- } \\
\text { ethe- } \\
\text { noid }\end{array}$ & $\begin{array}{l}\text { Poly- } \\
\text { ethe- } \\
\text { noid }\end{array}$ & Casein & $\begin{array}{l}\text { Egg } \\
\text { yolk }\end{array}$ & \\
\hline I Cholesterol-free & All & & $\stackrel{m g}{0}$ & $\begin{array}{l}g \\
0\end{array}$ & $\begin{array}{c}g \\
133\end{array}$ & 86 & $\begin{array}{c}\% \\
33.5\end{array}$ & $\begin{array}{c}\% \\
\mathbf{4 0 . 4}\end{array}$ & $\begin{array}{c}\% \\
27.6\end{array}$ & $\begin{array}{r}g \\
70\end{array}$ & $\begin{array}{l}g \\
\mathbf{0}\end{array}$ & $\begin{array}{c}g \\
0.3\end{array}$ \\
\hline 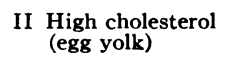 & $\begin{array}{l}\text { Group A } \\
\text { Group B } \\
\text { Group C }\end{array}$ & $\begin{array}{l}1,2 \\
3,4 \\
5,6\end{array}$ & $\begin{array}{r}475 \\
950 \\
1,425\end{array}$ & $\begin{array}{l}11 \\
22 \\
33\end{array}$ & $\begin{array}{l}122 \\
111 \\
100\end{array}$ & $\begin{array}{l}85 \\
84 \\
83\end{array}$ & $\begin{array}{l}33.7 \\
33.9 \\
34.0\end{array}$ & $\begin{array}{l}40.9 \\
41.2 \\
41.9\end{array}$ & $\begin{array}{l}26.8 \\
25.8 \\
25.3\end{array}$ & $\begin{array}{l}64.5 \\
58.9 \\
53.4\end{array}$ & $\begin{array}{r}5.5 \\
11.1 \\
16.6\end{array}$ & $\begin{array}{l}0.3 \\
0.5 \\
0.6\end{array}$ \\
\hline III Cholesterol-free & All & & $\mathbf{0}$ & $\mathbf{0}$ & 133 & 86 & 33.5 & 40.4 & 27.6 & 70 & $\mathbf{0}$ & 0.3 \\
\hline $\begin{array}{l}\text { IV High cholesterol } \\
\text { (crystalline } \\
\text { cholesterol) }\end{array}$ & $\begin{array}{l}\text { Group A } \\
\text { Group B } \\
\text { Group C }\end{array}$ & $\begin{array}{l}1,2 \\
3,4 \\
5,6\end{array}$ & $\begin{array}{l}1,200 \\
2,400 \\
3,600\end{array}$ & $\mathbf{0}$ & 133 & 86 & 33.5 & 40.4 & 27.6 & 70 & $\mathbf{0}$ & 0.3 \\
\hline
\end{tabular}

* All subjects received 3,000 calories for each dietary period. Carbohydrates: cornstarch $75 \mathrm{~g}$; Dextrimaltose no. 1 (Mead Johnson) $100 \mathrm{~g}$; sucrose $207 \mathrm{~g}$. Vitamins and minerals were added to meet the daily recommended allowance of the National Research Council and maintained

constant through all periods. During period II, 34, 68, and $102 \mathrm{~g}$ of egg yolk were given to groups A, B, and C, respectively.

extracted serum and immediately mixed with a stirring rod having a footplate. Although the Zak method for serum cholesterol provides results comparable with other methods (3), an analysis of each serum sample for total cholesterol was performed also in duplicate by the method of Abell, Levy, Brodie and Kendall (4). In all instances the results obtained for each of these healthy subjects un- der the different dietary conditions were comparable with the Zak method. The values reported are those determined by the Zak method.

For periods III and IV the total stool fat was determined with the Goldfish apparatus on 3-day collections.

The egg yolks fed in the experimental diet were pooled and an aliquot saved for chemical analysis. Cholesterol

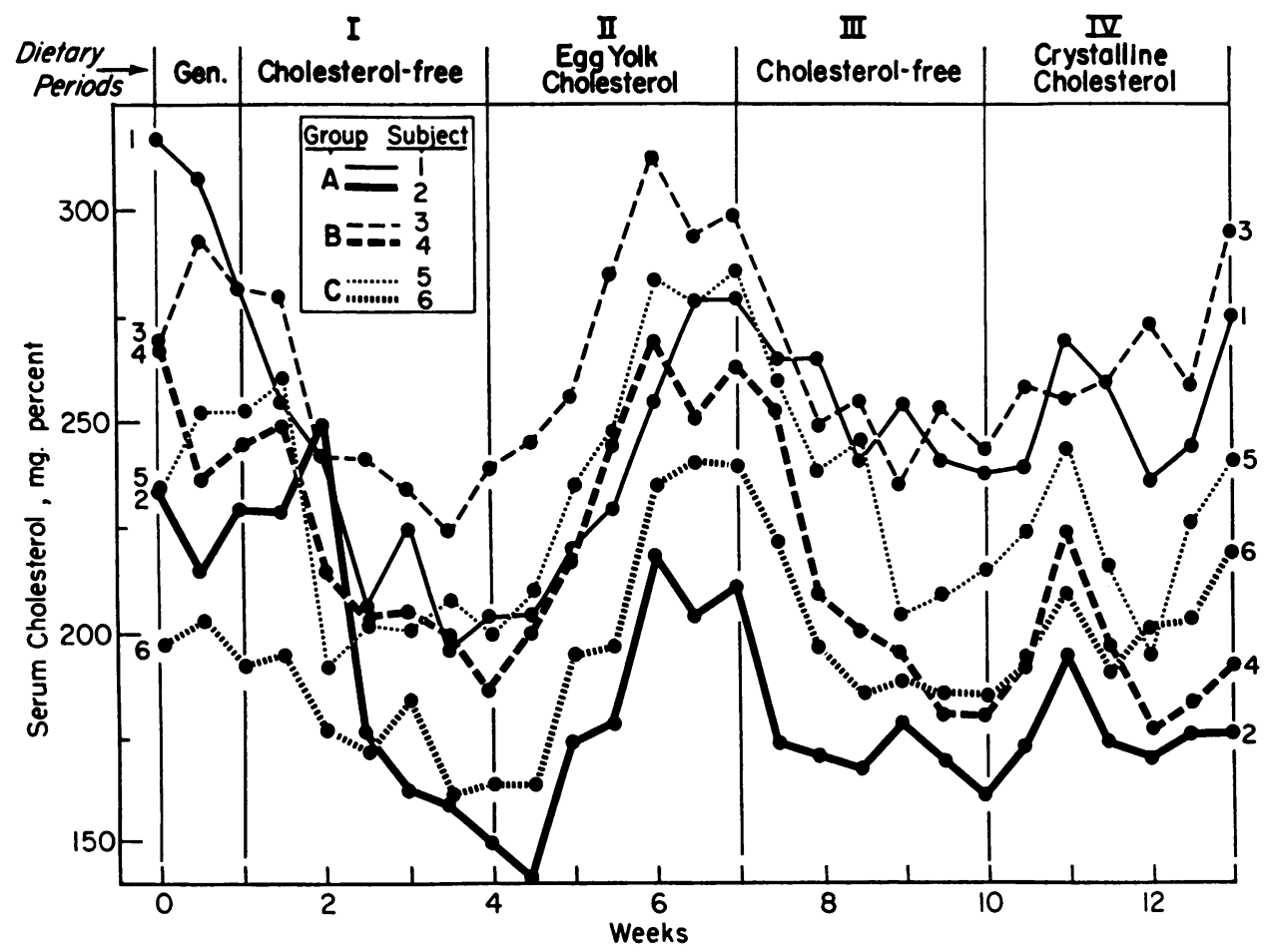

Fig. 1. The serum cholesterol values for each SUbJeCt during the different dietary PERIODS. In period II, group A subjects received $475 \mathrm{mg}$, group B $950 \mathrm{mg}$, and group C 1,425 $\mathrm{mg}$ of egg yolk cholesterol. In period IV, group A subjects received $1,200 \mathrm{mg}$ of crystalline cholesterol, group B $2,400 \mathrm{mg}$, and group C 3,600 mg. 
was determined by the method of Pihl (7). Phospholipid (5) and triglyceride (6) were determined on a chloroform-methanol extract. Values per $100 \mathrm{~g}$ of egg yolk were: cholesterol $1,370 \mathrm{mg}$, phospholipid $9.44 \mathrm{~g}$, and triglyceride $25.18 \mathrm{~g}$. These corresponded with previously reported analyses of egg yolk $(8,9)$.

Clinical course. The experimental subjects remained in good health for the duration of the study. They were examined daily; they took a constant amount of exercise each day; adherence to and tolerance of the formula were excellent. As might be expected with a 3,000 calorie intake, the smaller subjects $(2,3,4$ and 5$)$ gained weight moderately during each dietary period. The total gain for the 12 weeks was from 4 to 13 pounds in these subjects. The larger subjects ( 1 and 6 ) had no weight changes.

\section{RESULTS}

The serum cholesterol, phospholipid and triglyceride values for each of the six subjects during the different dietary periods are illustrated in Figure 1 and Table II. These normal men, con- suming a general diet, had a wide range of serum cholesterol concentration, varying from 198 to 295 $\mathrm{mg}$ per $100 \mathrm{ml}$ (mean 249). After 1.5 weeks of the cholesterol-free formula in period I, the serum cholesterol of all men declined considerably. The downward trend continued, and after 3 weeks the mean serum cholesterol reached 191 , or a mean change of $-58 \mathrm{mg}$ per $100 \mathrm{ml}(\mathrm{p}<0.01)$.

The addition of cholesterol in the form of egg yolk during period II for 3 weeks caused an increase in the serum cholesterol of each subject. The mean increase was 69 , or from 191 to $260 \mathrm{mg}$ per $100 \mathrm{ml}$ (Figure 2). For the group, this change was significant $(\mathrm{p}<0.001)$. The different amounts of dietary cholesterol led to similar responses. For example, the addition of $475 \mathrm{mg}$ of cholesterol to the diet produced a mean increase of $66 \mathrm{mg}$ per $100 \mathrm{ml}$ in the serum cholesterol for Subjects 1 and 2 of group A. Twice

TABLE II

Mean serum lipid values* for the different dietary periods

\begin{tabular}{|c|c|c|c|c|c|c|c|c|c|c|c|c|c|}
\hline & \multirow[b]{2}{*}{ Subject } & \multicolumn{3}{|c|}{ Period I } & \multicolumn{3}{|c|}{ Period II } & \multicolumn{3}{|c|}{ Period III } & \multicolumn{3}{|c|}{ Period IV } \\
\hline & & Initial & Final & Change & Initial & Final & Change & Initial & Final & Change & Initial & Final & Change \\
\hline \multirow[t]{2}{*}{ Cholesterol } & $\begin{array}{l}1 \\
2 \\
3 \\
4 \\
5 \\
6\end{array}$ & $\begin{array}{l}223 \\
295 \\
288 \\
241 \\
253 \\
198\end{array}$ & $\begin{array}{l}155 \\
201 \\
233 \\
194 \\
204 \\
164\end{array}$ & $\begin{array}{l}-68 \\
-94 \\
-55 \\
-47 \\
-49 \\
-34\end{array}$ & $\begin{array}{l}155 \\
201 \\
233 \\
194 \\
204 \\
164\end{array}$ & $\begin{array}{l}208 \\
280 \\
297 \\
257 \\
282 \\
240\end{array}$ & $\begin{array}{r}+53 \\
+79 \\
+64 \\
+63 \\
+78 \\
+76\end{array}$ & $\begin{array}{l}208 \\
280 \\
297 \\
257 \\
282 \\
240\end{array}$ & $\begin{array}{l}166 \\
240 \\
250 \\
181 \\
212 \\
185\end{array}$ & $\begin{array}{l}-42 \\
-40 \\
-47 \\
-76 \\
-70 \\
-55\end{array}$ & $\begin{array}{l}166 \\
240 \\
250 \\
181 \\
212 \\
185\end{array}$ & $\begin{array}{l}176 \\
261 \\
278 \\
191 \\
233 \\
211\end{array}$ & $\begin{array}{l}+10 \\
+21 \\
+28 \\
+10 \\
+21 \\
+26\end{array}$ \\
\hline & Mean & 249 & 191 & $\begin{array}{c}-58 \\
\mathrm{SE} \quad 8.5 \\
\mathrm{p}<0.01\end{array}$ & 191 & 260 & $\begin{array}{c}\mathrm{SE}^{+69} 4.3 \\
\mathrm{p}<0.001\end{array}$ & 260 & 205 & $\begin{array}{c}\mathrm{SE}^{-55} \\
\mathrm{p}<0.1 \\
<001\end{array}$ & 205 & 224 & $\begin{array}{c}\mathrm{SE}^{+19} \\
\mathrm{p}<0.01\end{array}$ \\
\hline \multirow[t]{2}{*}{ Phospholipid } & $\begin{array}{l}1 \\
2 \\
3 \\
4 \\
5 \\
6\end{array}$ & $\begin{array}{l}181 \\
214 \\
236 \\
194 \\
185 \\
177\end{array}$ & $\begin{array}{l}108 \\
150 \\
194 \\
164 \\
155 \\
152\end{array}$ & $\begin{array}{l}-73 \\
-64 \\
-42 \\
-30 \\
-30 \\
-25\end{array}$ & $\begin{array}{l}108 \\
150 \\
194 \\
164 \\
155 \\
152\end{array}$ & $\begin{array}{l}145 \\
208 \\
244 \\
203 \\
183 \\
193\end{array}$ & $\begin{array}{r}+33 \\
+58 \\
+50 \\
+39 \\
+27 \\
+41\end{array}$ & $\begin{array}{l}145 \\
208 \\
244 \\
203 \\
183 \\
193\end{array}$ & $\begin{array}{l}125 \\
170 \\
180 \\
144 \\
155 \\
138\end{array}$ & $\begin{array}{l}-20 \\
-38 \\
-64 \\
-59 \\
-27 \\
-55\end{array}$ & $\begin{array}{l}125 \\
170 \\
180 \\
144 \\
155 \\
138\end{array}$ & $\begin{array}{l}133 \\
191 \\
211 \\
156 \\
177 \\
178\end{array}$ & $\begin{array}{r}+8 \\
+21 \\
+31 \\
+12 \\
+22 \\
+40\end{array}$ \\
\hline & Mean & 198 & 154 & $\begin{array}{c}-44 \\
\mathrm{SE} \quad 8.2 \\
\mathrm{p}<0.01\end{array}$ & 154 & 196 & $\begin{array}{c}\quad+42 \\
\mathrm{SE} \quad 4.3 \\
\mathrm{p}<0.001\end{array}$ & 196 & 152 & $\begin{array}{c}\mathrm{SE}^{-44} \\
\mathrm{p}<0.01\end{array}$ & 152 & 174 & $\begin{array}{c}+22 \\
\mathrm{SE} \\
\mathrm{p}<0.01\end{array}$ \\
\hline \multirow[t]{2}{*}{ Triglyceride } & $\begin{array}{l}1 \\
2 \\
3 \\
4 \\
5 \\
6\end{array}$ & $\begin{array}{r}86 \\
118 \\
127 \\
103 \\
183 \\
91\end{array}$ & $\begin{array}{r}45 \\
78 \\
72 \\
66 \\
109 \\
58\end{array}$ & $\begin{array}{l}-41 \\
-40 \\
-55 \\
-37 \\
-74 \\
-33\end{array}$ & $\begin{array}{r}45 \\
78 \\
72 \\
66 \\
109 \\
58\end{array}$ & $\begin{array}{r}53 \\
130 \\
101 \\
93 \\
147 \\
103\end{array}$ & $\begin{array}{r}+8 \\
+52 \\
+29 \\
+27 \\
+38 \\
+45\end{array}$ & $\begin{array}{r}53 \\
130 \\
101 \\
93 \\
147 \\
103\end{array}$ & $\begin{array}{r}67 \\
128 \\
104 \\
72 \\
118 \\
102\end{array}$ & $\begin{array}{l}+14 \\
-2 \\
+3 \\
-21 \\
-29 \\
-\quad 1\end{array}$ & $\begin{array}{r}67 \\
128 \\
104 \\
72 \\
118 \\
102\end{array}$ & $\begin{array}{r}48 \\
125 \\
91 \\
71 \\
115 \\
119\end{array}$ & $\begin{array}{l}-19 \\
-\quad 5 \\
-31 \\
-1 \\
-3 \\
+17\end{array}$ \\
\hline & Mean & 118 & 71 & $\begin{array}{c}\mathrm{SE} \\
\mathrm{p}<0.3 \\
<0.001\end{array}$ & 71 & 104 & $\begin{array}{c}+33 \\
\mathrm{SE} \\
\mathrm{p}<0.3 \\
<0.01\end{array}$ & 104 & 98 & $\begin{array}{r}-6 \\
\mathrm{SE}<6.5 \\
\mathrm{p}<0.5\end{array}$ & 98 & 95 & $\begin{array}{r}-4 \\
\mathrm{SE} \quad 5.0 \\
\mathrm{p}<0.5\end{array}$ \\
\hline
\end{tabular}

* Computed on the basis of determinations made during the last week of each dietary period (mg per $100 \mathrm{ml})$. The initial values for period $I$ are those obtained during the week of the general diet directly preceding period I. SE $=$ the standard error of the mean or $\mathrm{SE}=\mathrm{SD} / \sqrt{\mathrm{N}}$. 


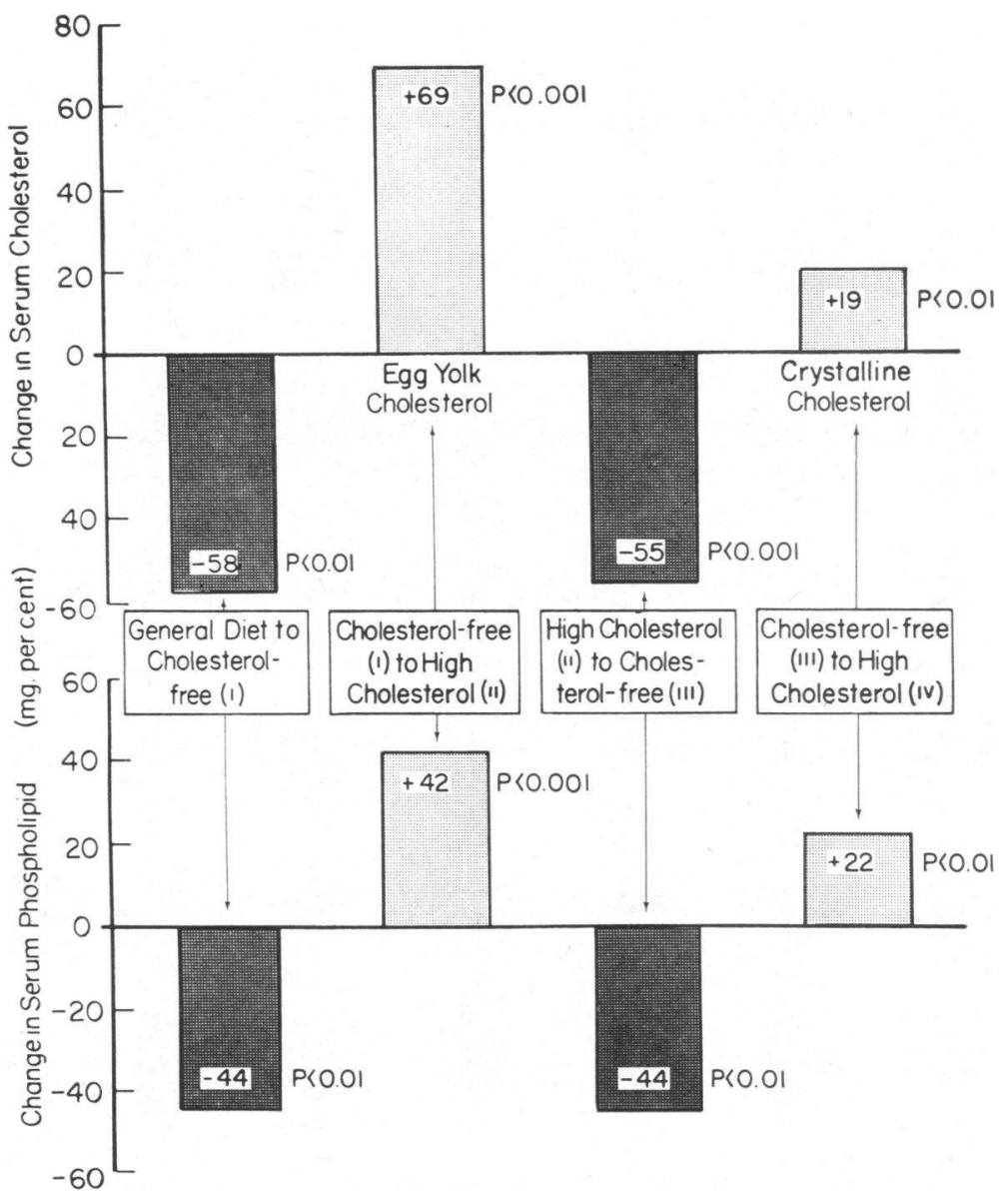

Fig. 2. The Changes IN SERUM ChOLESTEROL AND PHOSPholipid Which occurred as the diet WAS ALtered from one period to another. Mean values for the six subjects are given.

this amount of dietary cholesterol led to no greater serum cholesterol increase (mean $64 \mathrm{mg}$ per 100 $\mathrm{ml}$ ) for Subjects 3 and 4 of group B. Dietary cholesterol of $1,435 \mathrm{mg}$ given to Subjects 5 and 6 of group $\mathrm{C}$ led only to a slightly greater serum cholesterol change (mean $77 \mathrm{mg}$ per $100 \mathrm{ml}$ ).

The removal of cholesterol from the diet (period III) led to a considerable decrease in the serum cholesterol of each subject. After 3 weeks of this diet the mean decrease was -55 , or from 260 to $205 \mathrm{mg}$ per $100 \mathrm{ml}$ and was significant $(\mathrm{p}<0.001)$.

Crystalline cholesterol was then added to the diets for 3 weeks (period IV). The serum cholesterol concentration for each subject increased somewhat but much less than when cholesterol from egg yolk was given. The mean change was $19 \mathrm{mg}$ per $100 \mathrm{ml}(\mathrm{p}<0.01)$. The larger amounts of crystalline cholesterol did not seem to have greater effects on the serum cholesterol.

The serum phospholipid concentration for each subject changed in direction and amount as did the serum cholesterol for the different dietary periods. Initially, the consumption of the cholesterol-free diet resulted in a mean decline of 44 $\mathrm{mg}$ per $100 \mathrm{ml}(\mathrm{p}<0.01)$. The high cholesterol diet of egg yolk (period II) caused a rise in the mean serum phospholipid of $42 \mathrm{mg}$ per 100 $\mathrm{ml}(\mathrm{p}<0.001)$. The serum phospholipid increases were similar for groups A, B and C despite the feeding of different amounts of egg yolk cholesterol. The removal of egg yolk from the diet brought about a mean decrease in the serum phospholipid of $44 \mathrm{mg}$ per $100 \mathrm{ml}(\mathrm{p}<0.001)$. The mean serum phospholipid increased $22 \mathrm{mg}$ per $100 \mathrm{ml}(\mathrm{p}<0.01)$ when crystalline choles- 
terol was added to the diets. The larger quantities of crystalline cholesterol appeared to produce a somewhat greater increase in the serum phospholipid than did the smaller quantities.

The serum triglyceride changes were variable and appeared unrelated to dietary cholesterol. The greatest shift was the mean decrease of 47 $\mathrm{mg}$ per $100 \mathrm{ml}$, which occurred when the diet was shifted from general to cholesterol-free (period I). Serum triglyceride increased when egg yolk cholesterol was added (period II) but was not affected by either the cholesterol-free diet of period III or the crystalline cholesterol of period IV.

The excretion of lipids in the stool was within normal limits, at or less than 5 per cent, for formulas with and without cholesterol. Stool fat increased, however, during period IV when the formulas contained large quantities of crystalline cholesterol. A typical example was Subject 5. He excreted $2.0 \mathrm{~g}$ of fat on the cholesterol-free diet and $5.2 \mathrm{~g}$ of fat while consuming the diet containing $3,600 \mathrm{mg}$ of crystalline cholesterol per day. We infer that the bulk of this increase in lipid was unabsorbed dietary cholesterol, without the specific knowledge that the increase was in the sterol fraction.

\section{DISCUSSION}

In experimental animals, cholesterol is an important constituent of diets given to produce hypercholesterolemia and ultimately atherosclerosis (10). In man, on the contrary, most investigators have concluded that dietary cholesterol has little or no influence upon the serum cholesterol concentration $(11,12)$. Recent publications eliminate or omit any consideration of dietary cholesterol in the treatment and prevention of human hypercholesterolemia and atherosclerosis $(13,14)$. Emphasis has been placed upon dietary fat and protein and nondietary factors such as heredity, exercise and smoking.

A large number of experimental observations from Anitschkow's important report in 1913 to the present day has strengthened the concept that cholesterol in the diet is almost invariably essential for the production of atherosclerosis in animals. These species have ranged from the chicken to the monkey. Recently, Taylor, Cox, Counts and Yogi (15) have linked more closely human and experimental atherosclerosis. Extensive coronary atherosclerosis and myocardial infarction were produced in the monkey by the long-term feeding of a high cholesterol, 22 per cent butterfat diet.

In the present study, six healthy men had significant changes in the serum concentration of cholesterol in response to variations in their dietary intake of cholesterol. The total number of calories, the character and the amount of fat, the amount of protein and the amount of physical activity were maintained at a constant level, while only the amount of cholesterol in the diet was varied. Dietary cholesterol was first provided as egg yolk after the men had consumed a cholesterolfree diet for 3 weeks. The high cholesterol diet caused a prompt rise of the serum cholesterol concentration of each man by the end of 1 week. The removal of egg yolk cholesterol provided additional evidence of its influence upon serum cholesterol. The serum cholesterol of each man then decreased after 4 days of the cholesterol-free diet. For the next 2.5 weeks it continued to fall additionally. The changes in the serum phospholipid concentration of each man also correlated well with the presence or absence of cholesterol in the diet. In our previous study the high cholesterol and cholesterol-free diets were given for a longer period. The serum cholesterol and phospholipid changes induced by these diets were maintained for the entire 11 weeks of study (2).

Six egg yolks with a cholesterol content of 1,425 $\mathrm{mg}$ did not cause a greater rise in the serum cholesterol than did two egg yolks with one-third as much cholesterol. The review of Cook (16) and the work of Karvinen, Lin and Ivy (17) suggest that the human gastrointestinal tract has a limited capacity for cholesterol absorption. Perhaps all cholesterol above a certain amount is unabsorbed and passes out in the stool. The epidemiological study of Keys and co-workers provides data giving a similar line of evidence (11). Two large groups of Minnesota businessmen had similar serum cholesterol concentrations despite different cholesterol intakes of 401 and $1,010 \mathrm{mg}$ per day.

Crystalline cholesterol had a lesser effect upon the serum cholesterol and phospholipid concentrations than did egg yolk cholesterol despite the 
greater amounts of crystalline cholesterol which were consumed. The increased stool lipid during the period of the crystalline cholesterol formula suggested that cholesterol in this form might be poorly absorbed. Cook, Edwards and Riddell found that intestinal absorption of egg yolk cholesterol was four times more complete than was crystalline cholesterol dissolved in olive oil (18). The more effective absorption of egg yolk cholesterol may result from its dispersed state in lipoprotein complexes in the yolk.

The mechanism whereby dietary cholesterol augments the serum cholesterol concentration may be a matter of simple addition or it may be mediated through a more complex mechanism. First, after intestinal absorption, dietary cholesterol is transported in the chyle and later in the blood largely as a constituent of chylomicrons. When chylomicrons circulate in the blood, chylomicron cholesterol contributes to the total serum cholesterol (19). The continuance of chylomicron cholesterol in the blood probably depends upon the rapidity of chylomicron removal and hydrolysis by the liver and other tissues, but this is uncertain $(20,21)$. Second, cholesterol derived from the diet may recirculate as a higher density lipoprotein after chylomicron dissolution (21). In the rat, dietary cholesterol contributes as much as 90 per cent of the total serum cholesterol (22). In men given radio-labeled cholesterol, from 24 to 31 per cent of the serum cholesterol is derived from diet (23). The component of serum cholesterol not derived from the diet is of endogenous origin $(22,24)$.

Previous studies involving the effects of egg feeding upon the serum cholesterol concentration (25-27) are difficult to interpret, since they did not balance all of the variables between the control and experimental diets (2). Usually the egg yolk was an addition to a general diet and thereby caused a change in the fat content, fatty acid composition, calories and protein of the diet.

In the present study the egg yolk was not an addition. It was incorporated completely into the framework of the diet so that the cholesterol-free and egg yolk cholesterol formulas were identical in calories, protein and total fat. In particular, the differences in fatty acid composition between the two diets were negligible. The small quantity of arachidonic fatty acid fed only during the pe- riod of the egg yolk cholesterol formula might be expected to lower slightly the serum cholesterol, according to the studies of Nothman and Proger (28).

Cholesterol appears to be the necessary constituent of egg yolk that affects the serum cholesterol concentration (2). The phosphatide content of egg yolk would not be expected to have a direct hypercholesterolemic effect. Other phosphatides added to the diet have induced lowering of the serum cholesterol (29). It is not known whether egg yolk phosphatide enhances gastrointestinal absorption of egg yolk cholesterol. Bronte-Stewart has emphasized that egg yolk lipid elevates the serum cholesterol levels higher and more rapidly than does any other fat on a gram-for-gram basis (30). He has given evidence that both cholesterol and fat of a relatively high iodine value (i.e., 70) must be in the intestinal tract at the same time in order to achieve the hypercholesterolemic effects of cholesterol ingestion.

Beveridge, Connell, Mayer and Haust (31) recently reported that dietary cholesterol consumed with a butterfat fraction ( 30 per cent of the total calories) caused an increase in the serum cholesterol concentration. Their subjects consumed a fat-free formula for 8 days and for the next 8 days received a butterfat fraction plus cholesterol in amounts varying from 13 to $4,500 \mathrm{mg}$. In this study two variables in the diet, total fat and cholesterol, were altered. The serum cholesterol might be expected to increase when the fat alone was added to the diet. Nonetheless, the serum cholesterol concentration increased further by a significant amount when quantities up to $634 \mathrm{mg}$ of cholesterol were added to the diets of various groups.

The observations of the present study are compatible with the thesis that dietary cholesterol has an important effect upon the serum lipids in human beings (2). This does not deny the effects of the other factors, especially the influence of polyunsaturated fats in the diet. It is of interest that in this study a decided increase in the serum cholesterol concentration occurred from the ingestion of dietary cholesterol at the same time that a considerable amount of polyunsaturated fat (35 g) was present in the diet. The clinical implications of such a conclusion must await the results of further investigation. The possible role of 
dietary cholesterol should be considered in the design of diets given for the treatment and prevention of hypercholesterolemia.

\section{SUMMARY}

1. Six healthy men consumed in sequence a cholesterol-free diet, a diet containing cholesterol from egg yolk, a cholesterol-free diet, and a diet with added crystalline cholesterol. These diets were identical in calories, fat, protein, carbohydrate, minerals and vitamins. The fatty acid composition of the fat was also equivalent for all diets.

2. The addition of dietary cholesterol in the form of egg yolk caused a significant increase in the concentration of cholesterol and phospholipid in the serum. The serum cholesterol and phospholipid decreased greatly when egg yolk cholesterol was removed from the diet. Amounts of dietary cholesterol from 475 to $1,425 \mathrm{mg}$ per day (two to six egg yolks) produced similar effects. These amounts are within the average range of cholesterol consumption in the United States.

3 . When crystalline cholesterol was added to the cholesterol-free diet, less striking but significant increases in the serum cholesterol and phospholipid occurred.

4. These studies suggest that dietary cholesterol has a significant effect upon the serum cholesterol concentration in human beings.

\section{REFERENCES}

1. Connor, W. E., Hodges, R. E., and Bleiler, R. E. Serum lipids in men receiving high cholesterol and cholesterol-free diets (abstract). Circulation 1960, 22, 735 .

2. Connor, W. E., Hodges, R. E., and Bleiler, R. E. The effect of dietary cholesterol upon the serum lipid levels in man. J. Lab. clin. Med. 1961, 57, 331.

3. Zak, B. Simple rapid microtechnic for serum total cholesterol. Amer. J. clin. Path. 1957, 27, 583.

4. Abell, L. L., Levy, B. B., Brodie, B. B., and Kendall, F. E. A simplified method for the estimation of total cholesterol in serum and demonstration of its specificity. J. biol. Chem. 1952, 192, 357.

5. Dryer, R. L., Tammes, A. R., and Routh, J. I. The determination of phosphorus and phosphatase with N-phenyl-p-phenylenediamine. J. biol. Chem. 1957, 225, 177.

6. Van Handel, E., and Zilversmit, D. B. Micromethod for the direct determination of serum triglycerides. J. Lab. clin. Med. 1957, 50, 152.
7. Pihl, A. Cholesterol studies. I. The cholesterol content of foods. Scand. J. clin. Lab. Invest. 1952, 4, 115.

8. Hardinge, M. G., and Crooks, H. Fatty acid composition of food fats. J. Amer. diet. Ass. 1958, 34, 1065.

9. Deuel, H. J., Jr. The Lipids, Their Chemistry and Biochemistry, vol. II, Biochemistry. New York, Interscience, 1955 , pp. 810-813.

10. Katz, L. N., and Stamler, J. Experimental Atherosclerosis. Springfield, Ill., C. C Thomas, 1953.

11. Keys, A., Anderson, J. T., Mickelsen, O., Adelson, S. F., and Fidanza, F. Diet and serum cholesterol in man. Lack of effect of dietary cholesterol. J. Nutr. 1956, 59, 39.

12. Ahrens, E. H., Jr. Seminar on atherosclerosis: Nutritional factors and serum lipid levels. Amer. J. Med. 1957, 23, 928.

13. Pollack, H. Linoleic acid content of fats and oils. J. Amer. med. Ass. 1960, 172, 1164.

14. Olson, R. E. Diet and coronary artery disease. Circulation 1960, 22, 453.

15. Taylor, C. B., Cox, G. E., Counts, M., and Yogi, N. Fatal myocardial infarction in rhesus monkeys with diet-induced hypercholesterolemia (abstract). Circulation 1959, 20, 975.

16. Cook, R. P. Cholesterol. Chemistry, Biochemistry, and Pathology. New York, Academic Press, 1958.

17. Karvinen, E., Lin, T. M., and Ivy, A. C. Capacity of human intestine to absorb exogenous cholesterol. J. appl. Physiol. 1957, 11, 143.

18. Cook, R. P., Edwards, D. C., and Riddell, C. Cholesterol metabolism. 7. Cholesterol absorption and excretion in man. Biochem. J. 1956, 62, 225.

19. Connor, W. E. Effect of dietary lipids upon chylomicron composition in man. Fed. Proc. 1959, 18, 473.

20. French, J. E., and Morris, B. The tissue distribution and oxidation of ${ }^{14} \mathrm{C}$-labeled chylomicron fat injected intravenously in rats. J. Physiol. (Lond.) 1958, 140, 262.

21. Fredrickson, D. S., McCollester, D. L., Havel, R. J., and Ono, $K$. The early steps in transport and metabolism of exogenous triglyceride and cholesterol in Chemistry of Lipids as Related to Atherosclerosis, a Symposium, I. H. Page, Ed. Springfield, Ill., C. C Thomas, 1958, p. 205.

22. Morris, M. D., Chaikoff, I. L., Felts, J. M., Abraham, S., and Fansah, N. O. The origin of serum cholesterol in the rat: Diet versus synthesis. J. biol. Chem. 1957, 224, 1039.

23. Taylor, C. B., Patton, D., Yogi, N., and Cox, G. E. Diet as a source of serum cholesterol in man. Proc. Soc. exp. Biol. (N. Y.) 1960, 103, 768.

24. Gould, R. G., Taylor, C. B., Hagerman, J. S., Warner. I., and Campbell, D. J. Cholesterol metabolism. I. Effect of dietary cholesterol on the synthesis of cholesterol in dog tissue in vitro. J. biol. Chem. 1953, 201, 519. 
25. Okey, R., and Stewart, D. Diet and blood cholesterol in normal women. J. biol. Chem. 1933, 99, 717.

26. Steiner, A., and Domanski, B. Dietary hypercholesterolemia. Amer. J. med. Sci. 1941, 201, 820.

27. Messinger, W. J., Porosowska, Y., and Steele, J. M. Effect of feeding egg yolk and cholesterol on serum cholesterol levels. Arch. intern. Med. 1950, 86, 189.

28. Nothman, M. M., and Proger, S. On the effect of arachidonic acid on serum lipids in man. Fed. Proc. 1960, 19, 221.

29. Steiner, A., and Domanski, B. Effect of feeding of "soya lecithin" on serum cholesterol of man. Proc. Soc. exp. Biol. Med. (N. Y.) 1944, 55, 236.

30. Bronte-Stewart, B. Lipids and atherosclerosis. Fed. Proc. 1961, 20, pt. III, suppl. 7, 127.

31. Beveridge, J. M. R., Connell, W. F., Mayer, G. A., and Haust, H. L. The response of man to dietary cholesterol. J. Nutr. 1960, 71, 61. 